\title{
Re:formation - teser, tro og tvivl - Et dansk undervisningsprojekt om reformationen i børnehøjde
}

I 2017 er det jubiloumsår for reformationen. I den anledning udbyder Landsnetvcerket af Folkekirkelige Skoletjenester i Danmark et projekt til 5. og 6. klassetrin, hvor fokus både er på Martin Luther og hans tid og på følgerne af hans nye udloggning af kristendommen. Godt 30.000 danske skoleelever ${ }^{1}$ vil arbejde med reformationen i samarbejde med lokale folkekirker gennem projektet Re: formation - teser, tro og tvivl. ${ }^{2}$

Af Helle Krogh Madsen, teolog, prcest og daglig leder af Folkekirkens Skoletjeneste i KøbenhavnFrederiksberg. E-post: folkekirkens.skoletjeneste.147201@skolekom.dk

og Sidsel Leth Svensson, loerer og medarbejder ved Folkekirkens Skoletjeneste i Faxe, Stevns og Køge. E-post: sls@fsfisk.dk

\section{KORT OM PROJEKTET}

Målet med projektet er at eleverne skal have indsigt $i$, hvad det vil sige, at den danske folkekirke er en evangelisk-luthersk kirke og hvad evangelisk-luthersk kristendom er i dag. Endvidere skal de lære om og reflektere over, hvorfor reformationen opstod, hvordan den foregik og hvilken betydning reformationen har og har haft for kirke, kultur og samfund i Danmark.

Det samlede undervisningsforl $\emptyset \mathrm{b}$ gennemføres over 14 lektioner i fem faglige faser: Verden i 1500-tallet, Luther og Bibelen, bogtrykkerkunsten, reformationen i Danmark og fællessang. De fem faser giver tilsammen eleverne en grundlæggende faglig ballast om reformationen samt dens konsekvenser og forudsætninger i en dansk kontekst.

Projektets faglige omdrejningspunkt er fem små tegnefilm, som sammen med en række refleksionsspørgsmål indleder hver fase. Forskellige elementer herfra udfoldes efterfølgende og relateres til elevernes nutid.

Projektet er tænkt tværfagligt mellem kristendomskundskab ${ }^{3}$, historie og dansk og læreren benytter timer fra alle tre fag. Tilsvarende tager projektets faglige mål udgangspunkt i mål og læseplaner fra alle tre fag.

Lærere der tilmelder deres klasser modtager gratis:

- et projektintroducerende fagligt og metodisk kursustilbud for læreren

- en grundig lærervejledning med et konkret undervisningsoplæg samt faglig og pædagogisk vejledning

- adgang til en hjemmeside med projektmateriale - bl.a. fem korte tematiske

1 Der forventes i alt at deltage mellem 1000 og 1500 klasser i projektet. Tallet er et skøn med udgangspunkt i erfaringen fra tidligere landsprojekter.

2 Projektet udvikles af de danske folkekirkelige skoletjenester og arbejdsgruppen har bestået af forfatterne av denne artikkelen sammen med Peter Ulvsgaard, Anne-Birgitte Zoëga, Lene Thiim og Henriette Klausen. Projektet er støttet af Ministeriet for Børn, Undervisning og Ligestillling samt Præsidiet for Reformationsjubilæet 2017.

3 Kristendomskundskab er det danske religionsfag. Undervisningen er - modsat kirkens forkyndende undervisning - $100 \%$ kundskabsformidlende. Der arbejdes således historisk-kritisk med de religiøse helligskrifter og forestillinger. Fagets omdrejningspunkt er evangelisk-luthersk kristendom, men eleverne arbejder også med andre religioner og livsforestillinger. Det er muligt at blive fritaget fra faget - en mulighed kun $0,5 \%$ benytter. 
tegnefilm og en salme-rap, der tager udgangspunkt i Martin Luther og hans salmer

- klassesæt af elevbogen "re:minder" der indeholder refleksionsspørgsmål til de fem tegnefilm, billedmateriale, små fagtekster og en fortælling mv.

- manus til et såkaldt dogmeteater, som afvikles i en lokal kirke undervejs i projektet.

\section{Projektets Forl $\emptyset$ B:}

Læreren vil naturligvis tilrettelægge projektets forløb, så det passer til netop hans eller hendes elever. Men projektet lægger op til at forløbet ser ud som følgende:

\section{Fase 1: Verden i 1500-tallet}

Eleverne ser en kort tegnefilm om verden i 1500-tallet og dykker efterfølgende særligt ned i middelalderens helvedesangst. Formålet med denne fase er at er at give indsigt $i$ reformationstidens historiske kontekst, så de efterfølgende har forudsætninger for at reflektere over Martin Luthers tanker og kritik af kirken.

\section{Fase 2: Martin Luther og Bibelen} Eleverne ser en kort tegnefilm om Martin Luthers liv og dykker efterfølgende særligt ned i Luthers pointe om, at man ikke skal præstere noget for at være god nok over for Gud. Formålet med denne fase er at give eleverne indsigt $\mathrm{i}$ Bibelens betydning for Martin Luthers tro, tænkning og virke samt forudsætninger for at reflektere over hans tolkning af udvalgte bibeltekster.

\section{Dogmeteater}

Fase 1 og 2 samles op i et såkaldt dogmeteater i den lokale kirke. Dogmeteateret er enkelt teater med simpel forberedelse hvor elever, lærer og præst indlever sig i et lille teaterstykke og sammen fortæller en historie. Fortællingens udgangspunkt er Martin Luther. Der er ikke publikum ved dogmeteater. Fokus er elevernes leg og indlevelse.

\section{Fase 3: Bogtrykkerkunst}

Eleverne ser en kort tegnefilm om, hvordan bogtrykkerkunsten opstod og arbejder herefter særligt med satiretegninger. Formålet med denne fase er at give eleverne indsigt i, hvordan trykkekunsten revolutionerede måden at kommunikere på, og hvor afgørende den var for udbredelsen af reformationen. Eleverne skal endvidere reflektere over hvordan internettet har skabt en moderne kommunikationsrevolution.

\section{Fase 4: Reformationen i Danmark} Eleverne ser en kort tegnefilm om reformationen i Danmark og arbejder med både borgerkrigen Grevens fejde, de stridenes relationer og de nye superintendenter, som lokalt havde tilsyn med reformationen. Formålet med denne fase er at give eleverne indsigt $i$, hvordan reformationen forløb i Danmark og mulighed for at reflektere over, hvad reformationen betød for det enkelte menneske.

\section{Fase 5: Fællessang}

Eleverne ser en kort tegnefilm om, hvordan reformationen var med til at udvikle fællessang i kirken og arbejder herefter særligt med to Luther-salmer, som Per Vers har nyfortolket. Formålet med denne fase er at give eleverne indsigt $i$, hvordan reformationen skabte en fællessangstradition og redskaber til at kunne reflektere over indholdet af salmer. 
Metodiske OVERVEJELSER BAg PROJEKTET

\section{Tegnefilm}

Tegnefilm og animation er en naturlig del af børns medievirkelighed i fx computerspil, reklamer, internet, mobiltelefonen mv. Derfor danner de fem tegnefilm fundamentet for projektet ved at give en klar, detaljeret og dog kort introduktion til reformationen, hvor filmene med deres visuelle udtryk underst $\emptyset$ tter elevernes forståelse af et omfattende og svært tilgængeligt fagligt stof. I tegnefilmene er der derfor mulighed for at introducere komplekse begreber, og filmene kan gennem deres visuelle udtryk medvirke til at stimulere til abstrakt tænkning. Endvidere er filmene med til at rammesætte de efterfølgende elevopgaver.

\section{Den historiske fortælling}

Ud over tegnefilm benytter projektet den historiske fortælling som pædagogisk greb. Faglige forhold præsenteres her gennem en fortælling om de to søskende Jens og Karen, der oplever og reflekterer over reformationens hovedindhold. Jens og Karenfortællingerne anvendes som et narrativt greb til at give eleverne et personligt forhold til reformationen. Den historiske fortælling gør, at eleverne kan genkende deres egen personlige livsfortælling ved at spejle sig i fortællingens hovedpersoner.

\section{Dogmeteater}

Dogmeteateret handler om, at eleverne sammen leger, agerer og fortæller en historie. Historien om Martin Luther som den kunne have set ud - og ikke mindst med udgangspunkt i hvordan Martin går fra at være barn til at blive voksen.
Udgangspunktet for fortællingen er således det tidspunkt i livet hvor eleverne selv befinder sig. Det er yderligere en mulighed for, at klassen kan bruge teatergenren, uden nødvendigvis at skulle bruge flere ugers forberedelse. De elever, der vil, kan forberede sig meget, og de, der ikke vil, kan stille sig i baggrunden.

\section{Kirken som læringsrum}

Kirken anvendes som læringsrum i det integrerede dogmeteater for at åbne elevernes $\emptyset$ jne for de reformatoriske spor, som særligt er at finde $\mathrm{i}$ en middelalderkirke. Middelalderkirken stod, hvor den stadigt står, da reformationen blev gennemført, men kirkens inventar - prædikestol, døbefont, orgel og alter - (i moderne såvel som i middelalderkirker) vidner om centrale reformatoriske pointer. Disse genstande i kirkens rum kan eleverne både se og røre ved, og de har en lokal fortælling, som præsten kender og kan formidle.

Efter dogmeteateret, som eleverne selv spiller med i, kommer præsten på banen og samtaler med eleverne om hvordan kirkerummet og dets funktion ændrede sig som følge af Martin Luther og reformationen.

\section{LÆRINGSSYN}

Projektets læringssyn er socialkonstruktivistisk og er baseret på henholdsvis Vygotskys og Bruners læringsteorier om, at meningsfuld læring opstår i samarbejde med andre. Projektet lægger op til at eleverne lærer og arbejder i grupper, hvor de sammen fx reflekterer over givne spørgsmål til de fem film, formulerer nye spørgsmål til hinanden og sammen udfører opgaver og aktiviteter til de fem faser.

Bruner peger på, at konstruktion af viden og erkendelse fremmes gennem dia- 
log - i fællesskaber af gensidigt lærende, og at det således er gennem interaktion med andre, at man lærer. Sproget og metakognition ses her som kilder - kulturelle værktøjer til læring. Bruner mener derfor, at læreren skal opmuntre eleverne i at skabe lærende fællesskaber - og ikke fremstå som den, der har monopol på viden. Ydermere påpeger Bruner, at eleverne skal 'overføre' mentale præstationer til konkrete udtryk. I dette projekt skal eleverne eksempelvis i grupper udarbejde små film og fremstille flyveblade, hvilket er i tråd med Bruners tese om eksternalisering. Via et fælles produkt får grupperne synliggjort deres tanker og visioner, således at deres metakognition og refleksion bliver styrket.

Vygotskys syn på sociale læreprocesser er lig Bruners. Vygotsky er særlig kendt for begrebet 'zonen for nærmeste udvikling', som betegner det, som eleven kan på egen hånd, og det eleven gennem vejledning af en anden kan blive i stand til at gøre gennem mesterlære. Denne proces kræver ifølge Vygostsky en dialog, hvor eleven bliver udfordret i sin viden og sin forståelse. Sproget som mediering og mødet mellem forskellige perspektiver på det faglige stof udfordrer således den enkelte elevs viden. Samtale eleverne imellem om det faglige stof og elevernes brug af artefakter - her fx. ved at sætte bevægelse til en salme eller producere en musikvideo - medfører ifølge Vygotsky ny læring.

\section{Folkekirkelige SKoletJenester i DANMARK}

Danmarks folkekirkelige skoletjenester udarbejder lokalt og regionalt undervisningsforløb og projekter, der gør det lettere for skolen at samarbejde med folkekirken. Det gælder både muligheden for at trække på de faglige ressourcer som præster, organister, m.fl. har, og de muligheder der ligger $\mathrm{i}$ at inddrage kirkebygningen og kirkerummet i undervisningen. De pt 37 folkekirkelige skoletjenester i Danmark har meget forskellig tilblivelseshistorie og er derfor organiseret forskelligt, men samarbejder tæt og produktivt i Landsnetværket af folkekirkelige skoletjenester. Dette samarbejdet muliggør at der kan udbydes fælles landsprojekter ca. hvert andet år. Disse projekter knytter ofte til ved landsdækkende markeringer og jubilæer som nu i forbindelse med reformationsjubilæet. 